\title{
Study on Dynamic Mechanism of Industry-University Cooperation in Forestry Engineering Excellent Talents Training
}

\author{
Li Guangyao ${ }^{1}$, Yu Xiaohong ${ }^{1}$, He Yanli ${ }^{2}$, Jin Chunde ${ }^{1, ~ * ~}$ \\ ${ }^{1}$ College of Engineering, Zhejiang A \& F University, Hangzhou, China \\ ${ }^{2}$ College of Forestry, Hebei Agriculture University, Baoding, China
}

Email address:

jincd@zafu.edu.cn (Jin Chunde), lgy@zafu.edu.cn (Li Guangyao)

*Corresponding author

\section{To cite this article:}

Li Guangyao, Yu Xiaohong, He Yanli, Jin Chunde. Study on Dynamic Mechanism of Industry-University Cooperation in Forestry Engineering Excellent Talents Training. Science Journal of Education. Vol. 4, No. 6, 2016, pp. 214-221. doi: 10.11648/j.sjedu.20160406.18

Received: December 3, 2016; Accepted: December 17, 2016; Published: January 7, 2017

\begin{abstract}
Industry-university cooperation in forestry engineering excellent talents training is the basic way to cultivate qualified personnel in forestry universities. To construct dynamic mechanism of industry-university cooperation and promote the different parties as government, enterprises, universities and different trades to take part in are the key points to put the training into practice. However, the existing dynamic mechanism cannot bring out the enthusiasm of various parties to participate in the industry-university cooperation in forestry engineering excellent talents training. This paper systematically analyzes the related dynamic factors affecting cooperative training, sums up the problems of the existing dynamic mechanism and puts forward specific suggestions to improve the dynamic mechanism of industry-university cooperation in forestry engineering excellent talents training.
\end{abstract}

Keywords: Agriculture \& Forestry University, Industry-University Cooperation, Forestry Engineering Specialty, Excellent Talents Training, Dynamic Mechanism

\section{Introduction}

The cooperation between university and industry has become the focus of current global attention. The governments, universities, and industries are interested in good and effective collaboration which would be beneficial for all parties. To foster industry-university cooperation, and hence the knowledge and technology transfer between these two parties, academics, politicians and companies are paying attention to science and technology policies more than ever. Although several governments and research agencies are continually searching for ways to facilitate the interactions between industry and universities, hoping that they can increase the productive processes and the competitiveness of the collaboration environment, the academic circles have done a lot of useful research on this problem. The main research contents are focused on three aspects:

First, the reasons for lack of cooperation between the parties cultivate talents. The main reason of enterprises lack of participation in the university-industry cooperation enthusiasm is that they are not achieved a positive return of enterprises to enter into cooperative education and accept students practice in factories, only a small part of participation of students back to the original work of enterprises, enterprises obtain the final income from participating in the cooperative education is absence of significant [1]. The favorable social atmosphere and public opinion atmosphere of supporting cooperative education has not yet formed, the feasible legal basis of promoting the cooperative education is still no breakthrough, the effective institutional norms of leading the cooperative education as a guarantee system for the quality of higher education are not yet available [2].

Second, adverse consequences are arisen from the lack of talents training cooperation between the industries and universities. The actual skills and knowledge supply of students is difficult to meet the technical requirements of the labor market, the employment quality of college graduates is 
not optimistic and even there is a phenomenon of unemployment once graduation [3].

Third, the Countermeasures of cultivating talents in industry-university cooperation. Learning from foreign experience to formulate the policy of higher education cooperation in line with the national conditions and conform to the university and enterprise strategy by using the economic levers and take legal means to develop according to the situation of our country higher education cooperation policy, promote the sustainable development of higher industry-university cooperation education [4-5]. Strong interest driven is the driving force of industry-university cooperation, the key of dynamic mechanism construction of industry-university cooperation is how to meet the stakeholders to maximize the pursuit of benefits and format a win-win benefit driving mechanism, cooperation drive mechanism [6], cooperation choose mechanism, cooperation conductor mechanism and multi-communication and coordination mechanism can build up the mechanism of cultivation of creative talents [7-8].

These studies are of great significance in promoting the cooperative education, and it provide theoretical support for the research of dynamic mechanism of industry-university cooperation in forestry engineering excellent talents training.

\section{The Nature of Industry-University Cooperation Education and Mode of Collaboration Education}

In the development of education, the role of the University in the society is advancing with the times. At their foundation, the universities were apart from society and their role was to preserve the culture and knowledge of society. Over time, the function of the University extends to the social service [9]. The linkages between universities and industries have changed in both of the forms and the intensity of interaction. The primary mission of university is education - to train skilled and professional specialists for society. Until the19th century, the universities raised more concerns about research and thereby the universities started to social services [10].

The modern university produces a large number of scientific research results and disseminates them through a certain way, so that the industry and enterprise can make full use of their technical and intellectual advantage. Nowadays universities are becoming more and more entrepreneurial themselves and the relationships with industry and university are more direct and interactive. The universities of today have to find the appropriate balance between teaching, basic and applied research, and entrepreneurship, industryuniversity cooperation is formed under such conditions.

The generalized industry-university cooperation is a variety of cooperative activities between the educational institutions and the industry in the field of talent training, scientific research and technical services. Knowledge transfer encompasses highly interactive activities that include on- going formal and informal personal interactions, cooperative education, curriculum development, and personnel exchanges. Knowledge transfer mechanisms are the recruitment of recent university graduates and employing student interns, co-authoring of research papers by university and industrial firm members, industry-university consortia and, for example, also trade associations.

Cooperative education as one of the core contents of the industry-university cooperation, which combines learning in the classroom with studying in the work, and students apply theoretical knowledge to the relevant and rewarded practical work, and then take the challenges encountered and experience back to university, promote the level of university's teaching and learning. Cooperative education is not only in conformity with the cognitive law of "practice -cognition -- practice", but also in line with the educational policy of combining education with productive labor. A large sample survey shows that people's work skills, whether it is a professional hands-on operation ability, analysis and problem-solving skills, or planning, organization, communication skills to obtain more than $70 \%$ of the way from work experience. It further verifies the necessity of the combination of university and industry cooperation, theoretical study and practical work [11].

More specifically, industry-university cooperative education is the universities and industrial enterprises take advantages of their educational resources and environment, carrying out in-depth cooperation in resources, technology, teacher training, job training, student employment, research activities and other aspects of cooperation, combining organically the teaching environment which is mainly based on the indirect knowledge of the classroom and the direct access to the actual experience of the production site environment to adapt to the development of market economy, enterprises need for high-quality practical talents, and achieving a win-win situation talent training mode between universities and industries. To sum up, the essence of cooperative education is the education and cultivation of talents for economic and social development closely together, realize the benign interaction, its key is the cooperation and combination, mutual participation; its goal is strengthen the university's running efficiency, the enterprise's talent competitive advantage and promote the development of social economy.

According to the role of industry and university in the process of industry-university cooperation education, the common mode of industry-university cooperation education can be divided into two types of industries (enterprises) dominance and universities dominance.

The industries (enterprises) dominance is that the enterprise or production department is the main organizer and manager of the industry-university cooperation, the proportion of training is far greater than the proportion of the university teaching, or the proportion of the actual operation of teaching is greater than the proportion of the course theory study. The training are arranged around the curriculum and the needs of enterprises, the university, the trainees mostly 
signed agreement with company to ensure each other, each one takes what he needs [12].

The university dominance is that the university adhere to the university organization as the foundation when the cooperation education in the specific organization and implementation plan, based on the reality of the development of students, find the appropriate corporate employers according to the students' professional and interested, provide the corresponding production practice training places according to the needs of enterprises to carry out the cooperation education with industry.

\section{The Current Situation of Lacking Motives of Industry-University Cooperation in Forestry Engineering Excellent Talents Training}

\subsection{The Main Problems in Industry-University Cooperation in Talents Training for Enterprises}

- External factors. The lack of the legal, institutional and policy support and the requirement of participating in the industry-university cooperation, the lack of subsidies of human, material and financial resources to support enterprises to participate in talent training.

- Inner factors. Enterprises lack of systematic and longterm development strategy generally. Some of enterprises are still in a low level of duplication of operations; they didn't set up the business strategy based on enterprise life consciousness, absence a high level of corporate values; ignore the understanding and real identity in the behavioral science of the enterprises sustainable development; not aware of the strategic significance for technological innovation, standardized management, human resource development, business development etc.; most of them pursuit of short-term economic benefits as the supreme principle for being influenced by the narrow concept of operation and the environment, so that the enterprises participate in the industry-university cooperation is perfect popular utilitarian, the only pursuit is profit, in their ideals, the return of the industry-university cooperation is a kind of general market investment [13].

\subsection{The Main Problems in Industry-University Cooperation in Talents Training for Universities}

- External factors. At present, it is clear that the policy of national support for higher education to carry out industry-university cooperation, but the supporting and operational regulations are not perfect, the coordination mechanism of the cooperation is still not inadequate, especially the colleges and universities are managed by the administrative department of, they lack of direct and effective guidance from sectors and industries, most cooperation between universities an enterprises are sponsored in folk activities, responsibilities, rights, and provisions in the cooperation process is not standardized, no perfect mechanism to support the safeguard the cooperative relations, mostly rely on relationships or attitude of the cooperation on both sides, so it is hard to establish long-term, in-depth and stable cooperative relations.

- Inner factors. The education concept in some university is archaic, they still stay in the use of the subject based system; the teaching method is old fashioned and backward; teachers professional skills are poor and carry out practical teaching ineffectively, they can't walk out of the classroom and step into the enterprise; the course assessment method is single and focus on theoretical curriculum than practical course, it cannot reflect the high skilled personnel training objectives; The guide policy management mechanism in universities is imperfect, the training concept of " takes the service as the aim, take the employment as the guidance, take industry-university cooperation on education development road" for forestry engineering is not in place, it is difficult to joint enterprises to universities for some majors or major direction without market investigation and demonstration; Some universities still carry out industry-university cooperative education only as a way to solve the site for production practice and off campus practice in the original mode of education the student education mode, they never really consider that cultivate students' comprehensive quality and comprehensive ability, improve students' employment competitiveness as their primary task; they pay more attention to the sum of the practice base but not the quality of them, lack of rigorous plan for base construction, practice arrangement and scientific management; They used to focus on large enterprises or well-known enterprises, but ignore small and medium enterprises or private enterprises in the process of cooperation

\subsection{The Main Problems in Industry-University Cooperation in Talents Training for Industry Association}

- External factors. The untighten relationship between the industry organization and the university in talent training; industry association lack of the overall participation in the guidance of vocational education; the standard identification and quality supervision of vocational education and training lack of effective combination between university and industry, vocational qualification employment access system has not been established.

- Inner factors. To the forestry engineering industry association, the overall strength of is relatively weak, the personnel quality is not high, institutions are not perfect, office conditions and other issues are poor. The representation and cohesion industry is weak, it is difficult to obtain sufficient trust and support from related industries; the cooperative work carried out ineffective, in industry-university cooperation, the main 
functions of the industry association of "providing services, reflecting the demands and standardizing behavior" were not achieved.

\section{The Dynamic Mechanism Analysis of Industry-University Cooperation in Forestry Engineering Excellent Talents Training}

The dynamic mechanism of industry-university cooperation in talents training, which refers to the generation mechanism of necessary power for promoting the cooperative talents training, as well as the sum of integrated systems of various economic relations and organization system to maintain and improve the mechanism[14].

To discuss the dynamic factors of industry-university cooperation in talents training, it need to reply the resource of why and how to do cooperation between the two sides firstly, then need to study the dynamic factors of promoting the long-term and stability cooperation. If industry-university cooperation decisions are made in two aspects of external force and internal thrust, and the key lies in independent dynamic mechanism, that is the internal force, so it should be clear that what constitute the internal force and external thrust in the industry-university cooperation initiation and development stages, how do these factors play a role in promoting the cooperation development continually. When the investment and interest demands of both sides of the industry-university cooperation become clear, it need to analyze what is the actual effect of the external force or internal thrust to promote the cooperation on both sides, But before the study, it is obviously that the stakeholders who have impetus is different when the cooperation on the initial stage and subsequent development stages, so it is necessary to study respectively on cooperation at the beginning and subsequent development stage when analysis the cooperative impetus of both sides of industry-university cooperation.

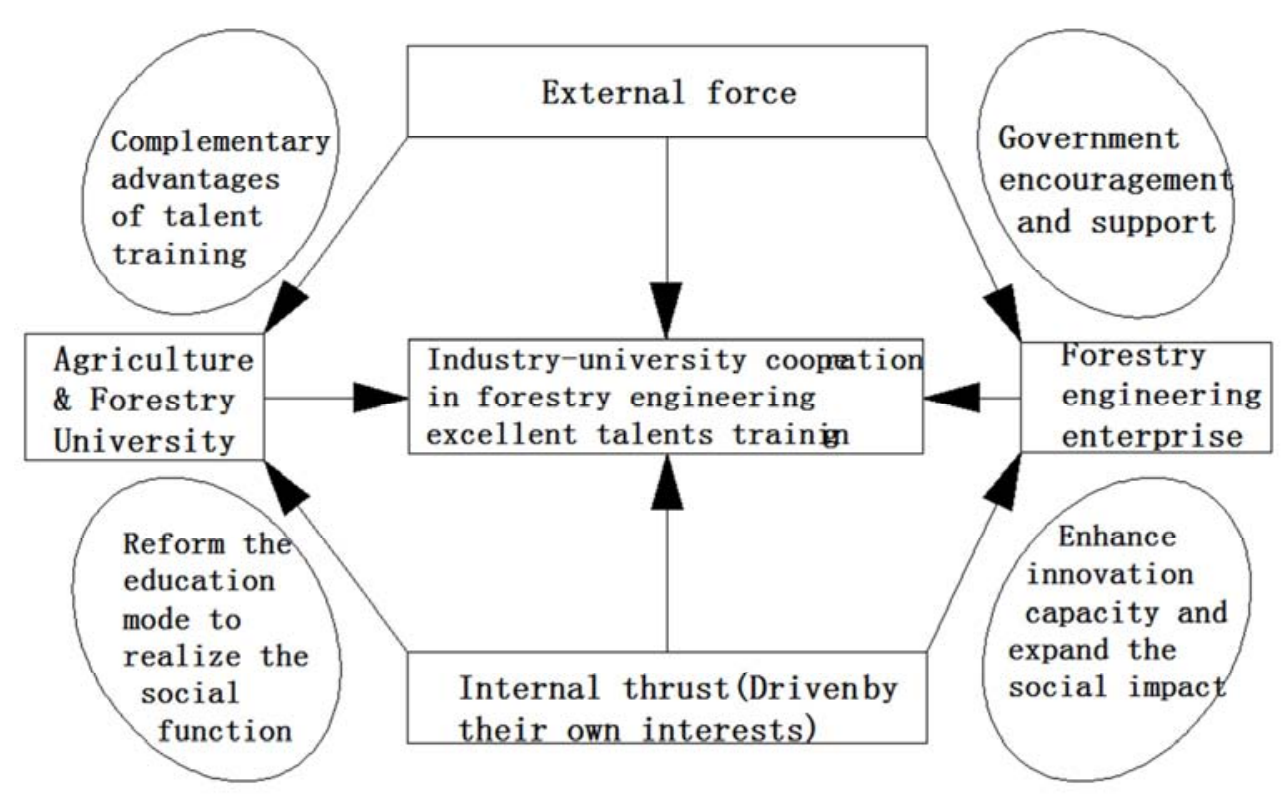

Figure 1. The dynamic mechanism of industry-university cooperation on the initial stage.

On the initial stage of industry-university cooperation, as shown in figure 2, encouraged and supported by the government, the complementary advantages of forestry colleges and forestry engineering industry provide the opportunity and objective possibility for the cooperation of forestry engineering talent training, driven by the interests of both sides, the cooperation are facilitated to cultivate high level and innovative forestry engineering talent for the common interests and common goals. The universities hope that it can increase forestry engineering strength, reform the talent training pattern of forestry engineering, improve the quality of talent education and enhance the function of serving the society through cooperation. The forestry engineering enterprise wish to strengthen their research force and reserve research talent, and expand the social influence by cooperation. It is constituted the initial dynamic of cooperation training forestry engineering talents which conclude in the expected return according to the advantages and disadvantages of universities and industry, the forestry universities and forestry industries are the primary stakeholders, constitute the leading party of industryuniversity cooperation is the beginning stage, the interest demand of both sides become the intrinsic motivation and the sustainable power source of the cooperation in talent training of the formation and development[15]. The government is the external forces, in which play an important role in promoting and stimulating the cooperation, but the degree of interests related to cooperation is not high, so it can only serve as secondary stakeholders in industry-university cooperation.

When the cooperation on road, on the one hand, the universities and the forestry industries still as independent 
organization to pursue their own interests, on the other hand, they formed a community of interests on the basis of common interests, interact with the five kinds related interests including teachers, administrators, students, government and enterprise [16]. It is obviously that this five kinds of stakeholders on cooperative effect is different, as the primary stakeholders is the universities and enterprises, they are the most important part of industry-university cooperation and undertake cooperative work and specific tasks, the group of students is cooperative achievements, their interests are closely related to the industry-university cooperation development, therefore, all of their pursuit of their own interests is the internal impetus for thrusting the cooperation. As the secondary stakeholders of the industry- university cooperation, the government and other investors are involved in different forms of funding, government support the development of industry-university cooperation by research funding, regulatory policies and research projects, the other investors funded by the capital or equipment, cooperation projects into the community. Although they are independent of each other with the industry-university cooperation, the government and other investors can influence the normal operation and development of the community greatly, even they detach from it more, their effects is comparable to that of the primary stakeholders. So, their interest demands constitute the external force to promote the development of industryuniversity cooperation.

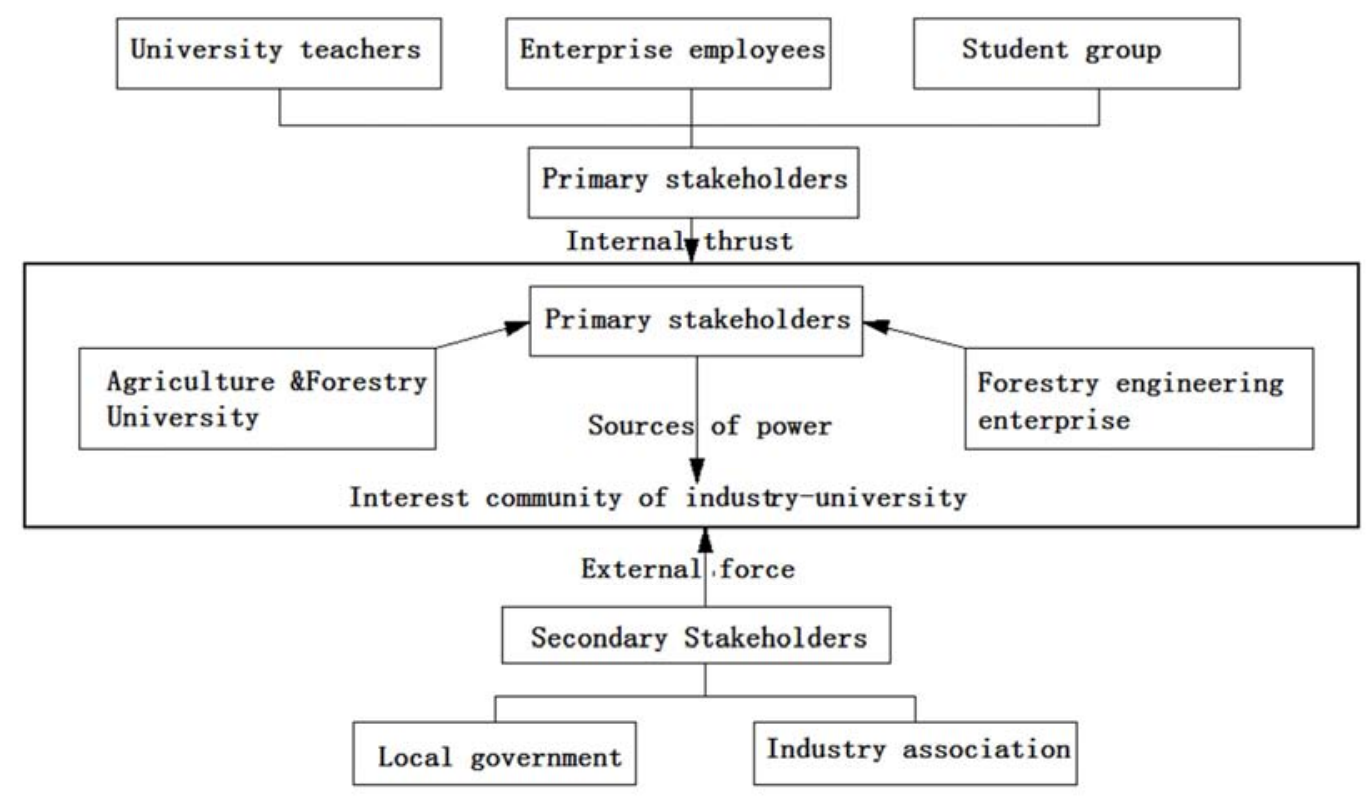

Figure 2. The sustainable development dynamic mechanism of industry-university cooperation.

The industry-university cooperation of forestry engineering talents training is formed and developed by the external force and internal thrust that constituted of the universities and enterprises, the stakeholders in the cooperation can get their respective interests and promote the long-term cooperation, and only the stable source dynamic of cooperation formed in endogenous demand which can ensure the forestry engineering talent training mode develop sustainable and healthy.

\section{The Dynamic Mechanism Establishment of Industry-University Cooperation in Forestry Engineering Excellent Talents Training}

It is the key factor of dynamic mechanism for promoting the industry-university cooperation in talents education that should establish and perfect the education-running mechanism, which are led by government, guided by industry, supported by enterprise, form the rules and regulations and strengthen the institutional construction for promoting the cooperation in running an university, the specific ways are as follows:

\subsection{Construct the Restraint Mechanisms for Promoting the Government to Participate in the Industry-University Cooperation in Talents Training}

Formulate and implement the basic law for the cooperation of the industry-university cooperation [17]. It should clarify the obligations and responsibilities of the government, enterprises, universities and other subjects in the cooperation. Among them, government as the promoter of national and regional cooperation in the cultivation of talents, on the one hand, it should establish the strategic objectives and planning for industry-university cooperation, draw up and planning and carrying out the laws, the rule and measures for promoting the cooperation;

Formulate relevant laws and regulations on the evaluation and supervision cooperation. That is to say, with legislation 
formation, gradually establishing occupation education development evaluation system that fit for the industryuniversity cooperation, promoting the optimization and upgrading the industrial structure, and making the government officials to change the political achievements, adhere to scientific and technological progress and innovation as an important support to accelerate the transformation of economic development mode, further implement the strategy of national rejuvenation through science and education, make the most of science and technology is the first productivity and talent is the first resource, improve the level of education modernization, enhance the ability of independent innovation, strengthen the innovative talents, accelerate the construction of innovative country.

Formulate and implement evaluation method of the industry-university cooperation in talent training. Through legislation, establish the standards on enterprises and regional cooperation talent training to promote the local government and enterprise to participate in the cooperation training more positive, so that improve the efficiency and effectiveness of cooperative education; with legislation, establish the system of cooperative education information disclosure and accountability for decision making, so it can clarify the social responsibility of enterprises, universities and government in industry-university cooperation in talents training, ensure the power of supervision attributable to public opinion and the public opinion, strengthen the restriction effect of cooperative responsibility.

\subsection{Construct the Beneficent Inducing Mechanism for Promoting the Enterprises to Participate in the Industry-University Cooperation in Talents Training}

Using economic measures to ensure that the actual economic benefits of enterprises from the industry-university cooperation in talents training is the key to construct the dynamic mechanism [18]. Its contents mainly include:

It should establish the concept that the enterprise is a kind of cooperation resource and form a set of system of paid use, make the enterprise resources enter the market as the basic resources and production factors, rules for their wear and tear compensation when they participate in cooperative talents education, so that it can promote the effective utilization of enterprise resources and make the enterprises dedicated to the industry-university cooperation in talents training.

Formulate fiscal and tax policies to support and encourage enterprises to participate in the talents training, such as, establish the preferential tax policies for enterprises with remarkable effect in the cooperative talents education, establish fiscal policy for construction of cooperation practice training base projects invested by government and strengthening the government's main body to cultivate talents investment, give financial subsidies to the technical R \& D and production projects which are conducive to participate in the training of talents.

Formulate incentive policies and measures to encourage enterprises to participate in the talents training, such as, establish the subsidy system for the enterprise to accept the practice of students, Encourage enterprises to form conception of cooperation in education, promote the economic development and product brand building for themselves, so as to obtain a better economic efficiency.

\subsection{Construct the Development Mechanism for Promoting the Universities to Participate in the Industry-University Cooperation in Talents Training}

Renew the educational concept of forestry engineering specialty talents training, break subject orientation thought and establish the concept that the industry-university cooperation is the only way to forestry engineering excellent talents training, update the teaching ideas, teaching means and teaching methods.

Strengthen the construction of forestry engineering specialty around the enterprise demand. It is necessary to carry on the investment of enterprise and industry when forestry engineering specialty and direction is set, so that can strengthen the pertinence of specialty construction, and lay the solid foundation for the seamless connection of industry and university.

Strengthen the construction of the "double qualification" team to improve the ability of teachers to satisfy the practice teaching, so that teachers can competent to the industryuniversity cooperation in talents training.

Strengthen the construction of practice training base, it is not only to strengthen the construction of practice training base on campus, but also to strengthen the construction of practical training base out of the campus by using the cooperation resource to training the qualified personnel.

\subsection{Construct the Communication Mechanism for Promoting the Industry Association to Participate in the Industry-University Cooperation in Talents Training}

Construct the information exchange mechanisms of industry and university, through establishing the sound and smooth information communication channel, on one hand, realize the information exchange and communication between the various departments in industry-university cooperation, on the other hand, rationalize the various relationships among institutions, so that the instructions, plans or decisions can be communicated timely and accurate, the efficiency of work can be enhanced higher.

Construct the exchange mechanisms of enterprise and university, it include the resource input, scientific research, talents training, external influence of the university and the main products, knowledge reserves, technology innovation, knowledge gap of the enterprise, it can express clearly the technical supply of the university and the talents and technical requirements of the enterprise by the information system.

Establish the information disclosure mechanism of the cooperation between the parties, all parties can cooperate in the situation of information transparency so that the supervision of all parties can be carried out and the cooperation is progressed smoothly. 


\subsection{Construct the Integrated Operating Mechanism for Promoting the Four Parties to Participate in the Industry-University Cooperation in Talents Training}

According to the adjustment of forestry engineering industrial structure and the changes of enterprises demand for qualified personnel, an industry-university cooperation steering committee with representatives of government, universities, enterprises and industry associations will be established to macro-regulate cooperation development, coordinate and solve problems encountered in the process of cooperation, provide advice and service for the development of cooperation.

Set up professional steering committee with representatives of the forestry engineering enterprise technical and management personnel, university teachers and education experts, which responsible for putting forward the forestry engineering specialty and direction setting and adjustment according to the present situation and the change of the demand of the talent market, handing out the forestry engineering specialty and direction training objectives, professional and position of the knowledge structure, standards of ability, requirements of skills training in accordance with the technical requirements of the employment post (Group), presenting teaching plans, curriculum standards, training syllabus, textbook compiling plan, standards and methods of knowledge and skills assessment on the basis of abilitycultivation-centered teaching thought, providing employment guidance and career development education for the forestry engineering specialties.

\section{Conclusion}

Creation of new knowledge is a source for survival of a nation in the 21 st century, and universities are responsible for creation of new knowledge. The relation between university and industry is a key to success. The respondents of the study were of the opinion that industry-university cooperation is a mean for advancement of new knowledge, industry is a place where new knowledge can be tested and its potential can be realized. The respondents agreed that through industryuniversity partnership, financial matters can be settled which ultimately beneficial for both.

In summary, cooperative cultivation of forestry engineering excellent talents is not only an education behavior but even more an economic behavior. As a system engineering, the internal values, interests in the system is showing a trend of diversification for it involve many subjects, in order to achieve in the cooperative education, the interests of all parties must be found to fully mobilize the enthusiasm of all sides. So that, with the developing in industry-university cooperation, it should further explore the dynamic factors of the cultivation of the talent training, fully stimulate the vitality and power of different subjects, establish a win-win dynamic mechanism, actively break the barriers of institutional and mechanisms, establish and perfect the dynamic mechanism of production and study cooperation. The effective mobilization of resources to actively participate in various forestry engineering innovative talents training of top-notch professional, collect all kinds of available resources to actively participate in forestry engineering top-notch innovative talent training.

\section{References}

[1] Zhang YanYing. Research on the dynamic mechanism of industry-university cooperation talent training in Xiamen. Journal of Xiamen Educational College. Feb. 2010, Vo. 112 No. 1, pp. 41-45. (in Chinese).

[2] Perkmann, M., Neely, A. and Walsh, K. How should firms evaluate success in university-industry alliances? A performance measurement system. R \& D Management, 2011, 41: 202-216.

[3] Gibbons, M. Changing Patterns of University-Industry Relations. Minerva, 2000, Vol. 38, No. 3, pp. 352-361.

[4] Etzkowitz, H. The Second Academic Revolution and the Rise of Entrepreneurial Science. 2001, IEEE Technology and Society Magazine, pp. 18-29.

[5] Adams, J. D., Chiang, E. P., Starkey, K., 2001. Industryuniversity cooperative research centers. The Journal of Technology Transfer 26 (1-2), 73-86.

[6] MA Bing, LUO Yingzi. Analysis of the dynamic mechanism of graduate students joint training program by universities and research institutes in the view of stakeholder theory. Meitan Higher education. May, 2015, Vol.33 No.3, pp. 57-60. (in Chinese).

[7] Belkhodja, O., Landry, R., 2007. "The Triple-Helix collaboration: Why do researchers collaborate with industry and the government? What are the factors that influence the perceived barriers?" Scientometrics 70 (2), 301-332.

[8] Davey, T., Baaken, T., Galan Muros, V., Meerman, A. The State of European University-Business Cooperation. Part of the DG Education and Culture Study on the Cooperation between Higher Education Institutions and Public and Private Organizations in Europe. 2011, 140 p.

[9] Brockliss, L. Gown and town: the university and the city in Europe, 1200-2000. Minerva, 2000, Vol. 38, No. 2, pp. 147-170.

[10] Etzkowitz, H. Innovation in Innovation: The Triple Helix of University-Industry-Government Relations. Social Science Information, 2003, Vol. 42, No. 3, pp. 293-337.

[11] Han hejun. The dynamic mechanism construction of industryuniversity cooperation in personnel training. Journal of Anhui Radio \& TV University. 2012, Vol. 1, pp. 89-93. (in Chinese).

[12] $\mathrm{Hu}$ chidi. Analysis of the stakeholders in higher education. Educational research, 2005 (3): 38-46. pp. 92-98. (in Chinese).

[13] Iqbal, A. M., Khan, A. S., Iqbal, S., Senin, A. A. Designing of Success Criteria-based Evaluation Model for Assessing the Research Collaboration between University and Industry. International Journal of Business Research and Management, 2011, Vol. 2, Issue 2, pp. 59-73.

[14] JIANG Hong, WANG Weixing, WANG Yongli. Dynamic model of cooperation in training talent for industry, university, institute, user and its application. Modern education management, 2013, Vol. 9, pp. 54-57. (in Chinese). 
[15] Linglong Chen. Optimizing the Industry-University Cooperation Process from the Perspective of Seamless Government Theory. International Journal of Business and Social Science.2015 January Vol. 6, No. 1, pp. 93-98.

[16] Perkmann, M., Walsh, K. The two faces of collaboration: impacts of university-industry relations on public research. Industrial and Corporate Change, 2009, Volume 18, Number 6, pp. 1033-1065.
[17] Santoro, M. D., Chakrabarti, A. K. Firm size and technology centrality in industry-university interactions. Research Policy, 2002, Vol. 31, pp. 1163-1180.

[18] Perkmann, M., Walsh, K. University-industry relationships and open innovation: Towards a research agenda. International Journal of Management Reviews, 2007, Vol. 9, No.4, pp. 259280 . 